issue, the authors suggest that UV radiation can be removed from the list of potential causes of amphibian die-offs.

Collins and Crump offer little comparison between amphibian declines and losses affecting other species. Organisms from lodgepole pines to African lions are dying en masse because of disease shifts that are linked to global warming and other environmental problems. For instance, in the wake of the European heatwave of 2003, many millions of invertebrate sea creatures, including sponges, molluscs and corals, died along several thousand kilometres of the northwest Mediterranean coastline. After studying a soft coral known as the red gorgonian, marine biologists Marc Bally and Joaquim
Garrabou of the University of the Mediterranean in Marseille, France, reported that the high temperatures favoured certain bacteria that ravaged the coral. In Italy, a team led by Ines Di Rosa at the University of Perugia and Daniele Canestrelli at the University of Tuscia in Viterbo proposes that the heatwave had similar consequences for some of Italy's amphibians.

By asking how long it will be before amphibians are safe from the chytrid fungus, Extinction in Our Times misses the bigger picture. The interacting changes threaten many life forms. Di Rosa, Canestrelli and their colleagues are studying how climate change and pathogen movement may conspire to cause amphibian die-offs. In Costa Rica, where such losses have accompanied climate-related changes in populations of birds, reptiles, mammals, insects and plants, we are studying orchids that have recently begun to die in the cloud forest. Amphibians belong to a chorus of canaries telling us one thing: Earth's life-support system is in trouble.

J. Alan Pounds is resident scientist at the Tropical Science Center's Monteverde Cloud Forest Preserve, Santa Elena, Puntarenas 5655-73, Costa Rica. Karen L. Masters is director of the Monteverde Program on Sustainability and the Environment of the Council for International Educational Exchange, Santa Elena, Puntarenas 5655-26, Costa Rica.

e-mail:goldtoad@racsa.co.cr

\title{
Newton and the money men
}

\section{Newton and the Counterfeiter: The Unknown Detective Career of the World's Greatest Scientist \\ by Thomas Levenson \\ Houghton Mifflin Harcourt/Faber and Faber: 2009. 336 pp. \$25/£20}

After the Glorious Revolution of 1688, in which King James II of England was overthrown by a union of Parliamentarians led by William of Orange, the English government found itself in dire financial straits. It had joined the War of the Grand Alliance against France in 1689, and was struggling to fund its army in a conflict that was to last for another 8 years. To make matters worse, the country was suffering from a lack of good coinage.

As Thomas Levenson explains in his engaging book Newton and the Counterfeiter, the government turned to an unlikely hero to save the nation from financial calamity - Isaac Newton.

In the 1660s, the English government had carried out a programme to machinemill the edges of coins to dissuade unscrupulous operators from 'clipping' the edges and melting down the clippings for personal gain. But by the 1690s, many milled coins had dropped out of circulation, partly because their face value was less than the value of the silver they were made from. This caused a crisis for the Treasury, which would not take clipped coins as payment for tax because they contained less silver. So in 1696, the Treasury resolved to take $£ 7$-million-worth of non-milled coins out of circulation (today's circulation is $£ 3.5$ billion or US $\$ 5.7$ billion), melt them down and re-coin them with milled edges.
Newton was brought in to manage this operation. An unlikely appointee for the role, he was at that time enjoying fame as the author of Principia Mathematica, his seminal work on the foundations of physics, and had just embarked on a radical change of career as a politician. Newton became the Member of Parliament for the University of Cambridge in the Convention Parliament of 1689, formed in the wake of James II's departure. But his efforts to acquire a senior public position in London came to nothing until early 1696 . Then, with the backing of his patron Charles Montagu Chancellor of the Exchequer and 1st Earl of Halifax - Newton was awarded the position of Warden of the Royal Mint.

Although the job had been treated as a sinecure by most of his predecessors, Newton took it on with vigour. He masterfully oversaw the great re-coinage and, after overcoming

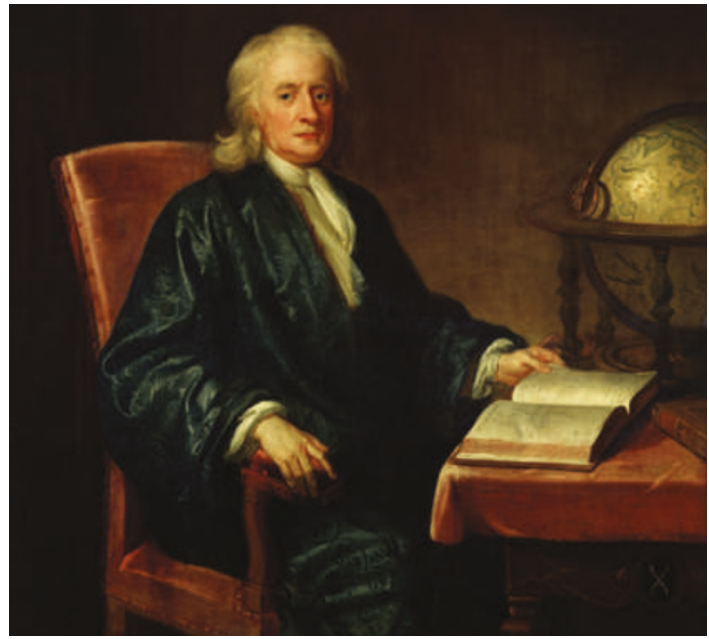

As Warden of the Royal Mint, Isaac Newton used his genius to investigate and convict a similarly intellectual counterfeiter. his initial revulsion, prosecuted with relish the clippers and 'coiners', or counterfeiters, who were partly responsible for the disarray of the country's currency. It wasn't long before his role brought him up against the arch-counterfeiter and forger, William Chaloner, whose skill and success in faking French pistoles (gold coins) and English guineas had quickly taken him from poverty to riches.

The book documents the entertaining relationship between these two geniuses and the different worlds they inhabited. Although their story is well known to historians of science, Levenson's account adds substantially to our knowledge of the social and political background against which it played out. The author manages to unpick many of the tangled and morally ambiguous webs that made up the metropolitan counterfeiting culture of that era, and shows - impressively, given the scant sources available - how Chaloner pulled off many of his brazen schemes.

It is an enthralling tale. At one point, Chaloner became wealthy enough to live in a large house in central London, but just as quickly lost whatever fortune he had made. He bounced back in his typical extraordinary fashion. In February 1697, he managed to convince a Parliamentary committee that was investigating alleged abuses at the Royal Mint - the allegations had come from Chaloner himself - that he could oversee a much more efficient way of producing coinage than the method that was in use.

Newton showed that Chaloner's scheme was unworkable. However, within a year the trickster had distributed a document making further accusations of corruption against members of the Mint, this time alluding to the activities of the warden himself. Again his claims were taken seriously, and Newton and others were 
investigated by the most senior members of the Treasury. Newton then put all of his energies into preparing a careful case against his rival, personally interrogating a number of Chaloner's former associates, and at a trial in March 1699 secured a conviction against him for counterfeiting. Chaloner feigned madness for a time - his final sham - but was hanged the same month.

Newton and the Counterfeiter contains the odd error of fact, and Levenson is on sticky historical ground with his claims about the wider contexts of the events he describes. A more conspicuous drawback is the author's failure to consider Newton's feud with Chaloner in the light of his battles with other luminaries of that era, such as Robert Hooke and Gottfried Leibniz, or even Newton's relentless denunciation of the fourth-century Saint Athanasius - in his view, the propagator of the corrupt doctrine of the Holy Trinity. Privately, Newton expended a vast amount of time examining the morals and actions of people such as Athanasius, and finding them guilty of crimes against Christianity.
Newton may have known next to nothing about prosecuting clippers and coiners, as Levenson correctly notes, but once it became personal, Chaloner stood little chance against a man who spent much of his life cutting much larger intellectual heavyweights down to size.

Robert Iliffe is professor of intellectual history and the history of science in the Department of History, University of Sussex, Brighton BN1 9RH, UK; author of Newton: A Very Short Introduction; and editorial director of the Newton Project (www.newtonproject.sussex.ac.uk).

\section{Florence's observatory restored}

\section{Torrino della Specola \\ Museum of Natural History, Florence Opens 7 November}

Newly restored, an elegant eighteenth-century astronomical observatory in Florence, Italy, reopens to the public this week after 135 years.

Its builder, Italian polymath Felice Fontana, had rushed from Pisa across the hills of Tuscany, bursting with zeal. The Grand Duke Pietro Leopardo had chosen him to direct his new Museum of Physics and Natural History in Florence, which opened to the public in 1775 . Fontana now had carte blanche to realize his Utopian dream: a museum in which all that was known of nature could be brought into a single building for the edification of the people, and for scientists to make yet more discoveries. It would be a pinnacle of Enlightenment endeavour, and Fontana intended it to be on a par with Florence's unequalled fine-art collections.

The Grand Duke commissioned the restructuring of the medieval Torrigiani palace for the museum, ensuring its prominent position between two Renaissance landmarks: the monumental Pitti palace and the formal, sculpture-filled Boboli gardens.

Fontana threw himself into acquiring collections based on natural history, botany, mineralogy and more - as well as commissioning the wax anatomical and botanical models for which Florence is justly famous (see Nature 452, 414; 2008). Astronomy, neglected by the city since Galileo's death there in 1642, was to be a major activity. So the Torrigiani palace was reinforced to bear the weight of a 35-metre-high observation tower, the Torrino della Specola.

This was an unpopular move. Even the observatory's first director, Domenico de Vecchi, was outspokenly critical of its logistical virtues. "For all its elegance, it is not the most favourable for observations, nor the most comfortable for observers," he wrote in 1808, a year after he was appointed director.

Indeed, few astronomers approved. The modern trend was to build observatories away from towns and above the mist, on top of hills where there was plenty of space. The observatory tower was simply cramped - the architect had built it without consulting astronomers and had failed to provide space for them to

The observatory tower remained closed, but has now been renovated to its original glory. It reopens as an extension to the museum on 7 November, in this International Year of Astronomy that marks the 400th anniversary of Galileo's first observations with a telescope.

There are three good reasons to visit. First is the exhibition. Paying homage to Fontana's vision of the all-inclusive scientific centre, the tower displays representative artefacts from the original collections - ornaments acquired by Captain James Cook; two bewilderingly life-

like magnolia and lotus flowers made of wax; a Medici collection of worked gemstones; an ancient herbarium; some fossils, a pair of taxidermically prepared lion monkeys; a few historic telescopes and a couple of still-life paintings by Bartolomeo Bimbi. The displays are not extensive - the space hasn't got any larger in the past two centuries - but they are fine examples.

Second, the architecture is a work of art - octagonal rooms, gracious windows and elegant, narrow spiral staircases. Most astounding is the Meridian Room, whose supporting arches are stuccoed with slender storks in the act of

retire to their books or writing tables. Annoyingly, the perfect hill was there for the taking - Arcetri, overlooking Florence, where Galileo had made his last home. Galileo's residence, known as Il Gioiello, or The Jewel, was restored and reopened earlier this year.

But Fontana was unshakably wedded to his vision of the all-encompassing museum and science centre. He resisted incessant calls to relocate the observatory. Fontana died in 1805 , but more than 60 years passed before pragmatism finally won out and in 1872 , the astronomers moved to a new observatory on Arcetri, which still operates today. By then, Fontana's Utopia was being broken up, with many collections being distributed to other sites in Florence, including the university. Only the natural-history and anatomical collections remained in the museum. taking flight. A marble meridian inlaid into the floor, decorated in copper and silver, indicates the hour and time of year. When astronomers used this room for observations, a narrow slit in the walls and roof could be opened to expose a $180^{\circ}$ slice of the sky. Eight large windows and an outside terrace allowed an unobstructed view of the whole sky.

The third reason to visit the tower is its superb location. Its elevation allows a unique and commanding view of one of the world's most beautiful cities - a panorama that has not been seen by the public for 135 years.

Alison Abbott is Nature's senior European correspondent.

For more details on the observatory tower, see www.msn.unifi.it. See go.nature.com/V52qT5 for articles in the hidden treasures series. 